\title{
The Development of Vocabulary in Bahasa Indonesia Textbook for Senior High School
}

\author{
Kisyani \\ Universitas Negeri Surabaya \\ Surabaya, Indonesia \\ kisyania@unesa.ac.id \\ Mintowati \\ Universitas Negeri Surabaya \\ Surabaya, Indonesia \\ mintowati@unesa.ac.id
}

\author{
Fafi Inayatillah \\ Universitas Negeri Surabaya \\ Surabaya, Indonesia \\ fafiinayatillah@mhs.unesa.ac.id \\ Mukzamila \\ Universitas Negeri Surabaya \\ Surabaya, Indonesia \\ mukzamila@unesa.ac.id
}

\begin{abstract}
Vocabulary is the most basic part of a language. The more vocabularies a person has, the more competent that person is in communicating. Mastery of vocabulary as a material for one's communication should be developed throughout life because the language is always evolving. Related to this, the paper aims to describe (1) the development of vocabulary in high school student books, (2) favorite entries, and (2) learning scenarios for vocabulary development. To disclose these, this research uses the entry application, basic vocabulary list, and literacy strategies in learning. The results of the analysis show that (1) the development of the number of Indonesian language entries in the high school student's book is not good, (2) favorite entries of SMA are "yang" and "dan"; (3) Learning scenarios in vocabulary development can be carried out by various means using other sources outside the student's book to further enrich the vocabulary. This is accompanied by a literacy strategy in learning. The results of this study can be used by teachers to further improve learning so that the development of high school students will be better.
\end{abstract}

Keywords--- vocabulary, learning scenario, entry application, literacy strategy in learning

\section{INTRODUCTION}

Vocabulary is the most basic part of a language. The higher a person's education should be the more vocabulary he or she has. The more vocabularies a person has, the more competent that person is in communicating. Mastery of vocabulary as a material for one's communication should be developed throughout life. This is because language is always evolving. In this case, the Indonesian vocabulary has always improved. This is shown in the Indonesian Big Dictionary (KBBI) with the following developments: 62,100 entries (edition I, 1998); 72,000 (edition II, 1991); 78,000 (issue III, 2005); 90,000 (IV edition, 2008), 127.036 (edition V, 2016).

Furthermore, in the 1994 Curriculum it was mentioned that elementary school graduates should have mastered 9,000 vocabularies, 15,000 for junior high school, and 18,000 for high school[1]. However, in a competency-based curriculum, it changed, high school graduates were said to master 12,000 vocabulary[2]. Unfortunately, there was no limit on vocabulary mastery in the 2013 curriculum[3].

In relation to vocabulary development, literacy strategies in learning can be applied, primarily by using other sources (other than student books) closely related to vocabulary development [4]. Educators need to designate life-related sources with diverse texts (including multimodal text) with varying vocabulary. Therefore, in learning Indonesian language, the development of vocabulary with reference to other sources needs to be done so that the development of vocabulary becomes more directed. Thus, the vocabulary of learners and educators will grow.

Based on this, this paper aims: (1) to describe the development of vocabulary in high school students' books; (2) describe the learning scenario for vocabulary development.

\section{METHOD}

This research will be an example of Transformative research which this research not only focus on solving research problems but also involving researchers as novice researchers in self-study of in-depth researchers and the practice of professional world researchers [1].

\section{DISCUSSION}

\section{Word and Entry in High School Student Book}

The number of words used in the High School Student Book (Curriculum 2013) is calculated by the entry application. There is still a weakness of the application associated with two or more words that are identified into one word (one entry) because file.pdf presents something of the sort. Therefore, it is very likely that the results of the calculation of the entry are fewer than those presented here. Temporary solution: file.pdf changed to word then converted 
back to pdf. However, in terms of results, because using the same application it does not have much effect.

The results of the analysis presented in this paper come from[9]. Here is a table of the development of words and entries contained in the book high school students.

TABLE I. WORD AND ENTRY IN HIGH SCHOOL STUDENT BOOK

\begin{tabular}{|c|c|c|c|c|}
\hline \multirow{2}{*}{ DESCRIPTION } & \multicolumn{4}{|c|}{ GRADE } \\
\hline & $X$ & $X I$ & $X I I \_I$ & $X I I \_2$ \\
\hline \multirow{2}{*}{ Number of pages } & \multirow{2}{*}{296} & \multirow{2}{*}{312} & 208 & 248 \\
\hline & & & \multicolumn{2}{|c|}{456} \\
\hline \multirow{2}{*}{ Number of words } & \multirow{2}{*}{57064} & \multirow{2}{*}{58744} & 30408 & 40354 \\
\hline & & & \multicolumn{2}{|c|}{70762} \\
\hline Number of entries & 4980 & 5262 & 3052 & 4134 \\
\hline
\end{tabular}

Based on the content and number of pages, grade XII book is split into two. Therefore there are four books. Based on these four books, the number of words and entries from grade $\mathrm{X}$ to grade XI and continuing to grade XII seems to be rising. The number of pages and words for grade XII can be directly added, but the number of entries cannot be. The table 1 indicates that the highest number of entries is in grade $\mathrm{X}$. In grade XII the number of entries each semester is actually smaller than grade XI and grade X.

Furthermore, the following is a comparison with similar research that has been done.

\section{TABLE II. COMPARISON OF READING VOCABULARY FOR VARIOUS LEVELS}

\begin{tabular}{|c|c|c|c|c|}
\hline Grade & American & Zuhdi & Sarwadi & $\begin{array}{c}\text { Kisyani et al }(2017 \\
\text { grades } 7-9 ; \\
2018 \text { grades } 10- \\
12)\end{array}$ \\
\hline 1 & 3000 & & & \\
\hline 3 & \multirow{7}{*}{86.741} & & & \\
\hline 4 & & 3.253 & & \\
\hline 5 & & 3.727 & & \\
\hline 6 & & 3.244 & 4000 & \\
\hline 7 & & & & 5.045 \\
\hline 8 & & & & 4.889 \\
\hline 9 & & & & 3.120 \\
\hline 10 & & & & 4.980 \\
\hline 11 & & & & 5.262 \\
\hline $12-1$ & & & & 3.052 \\
\hline $12-2$ & & & & 4.134 \\
\hline
\end{tabular}

Based on the table it appears that the development of entry in high school declined, especially when compared with the results of research [10], [11], [9] and the entries developed in books in America (86.741). The American study of reading vocabulary is based on 1,045 samples taken from various readings for grades 3-9. The list contains 86,741 entries [12]. With the highest number of 5,262 (even tending to decrease), it means that high school students are only introduced by exposing about $29 \%$ of them if based on curriculum provisions calling 18,000 (1994 curriculum) or about $44 \%$ of the provision of competency-based curriculum that lists 12,000 . Compared to the 127,036 Indonesian entries in Bahasa Indonesia (KBBI edition V), only about $4 \%$ of the entries were introduced to high school students. This indicates that the book of Indonesian High School students need to further develop (add) the use of vocabulary to read and develop it.

\section{Favorite Entry}

Favorite entry is a lot of / frequent entry in the text. This shows the focus of the discussion. The favorite entry in the junior high school book is as follows.

TABLE III. FAVORITE ENTRY

\begin{tabular}{|c|c|c|c|c|c|c|c|c|}
\hline \multirow{3}{*}{$\begin{array}{l}\mathbf{N} \\
\mathbf{O}\end{array}$} & \multicolumn{8}{|c|}{ GRADE } \\
\hline & \multicolumn{2}{|c|}{$X$} & \multicolumn{2}{|c|}{$X I$} & \multicolumn{2}{|c|}{$X I I-1$} & \multicolumn{2}{|c|}{$X I I-2$} \\
\hline & $\begin{array}{c}\text { Entr } \\
y\end{array}$ & $\begin{array}{c}\text { Num } \\
\text { ber }\end{array}$ & $\begin{array}{c}\text { Entr } \\
y\end{array}$ & $\begin{array}{c}\text { Num } \\
\text { ber }\end{array}$ & Entry & $\begin{array}{c}\text { Num } \\
\text { ber }\end{array}$ & Entry & $\begin{array}{c}\text { Num } \\
\text { ber }\end{array}$ \\
\hline 1 & $\begin{array}{c}\text { yan } \\
\text { g }\end{array}$ & 1882 & $\begin{array}{c}\text { Yan } \\
\mathrm{g}\end{array}$ & 2093 & Yang & 1072 & yang & 1507 \\
\hline 2 & dan & 1350 & Dan & 1394 & Dan & 607 & dan & 962 \\
\hline 3 & $\begin{array}{l}\text { den } \\
\text { gan }\end{array}$ & 807 & $\begin{array}{c}\text { Dala } \\
\text { m }\end{array}$ & 886 & Teks & 495 & di & 559 \\
\hline 4 & $\begin{array}{c}\text { dala } \\
\text { m }\end{array}$ & 803 & $\begin{array}{l}\text { Den } \\
\text { gan }\end{array}$ & 872 & Di & 478 & $\begin{array}{c}\text { denga } \\
\mathrm{n}\end{array}$ & 519 \\
\hline 5 & Di & 718 & Itu & 778 & $\begin{array}{c}\text { Kalia } \\
\mathrm{n}\end{array}$ & 418 & dalam & 475 \\
\hline 6 & Ini & 586 & Di & 762 & Pada & 412 & teks & 473 \\
\hline 7 & $\begin{array}{c}\text { dapa } \\
\mathrm{t}\end{array}$ & 586 & Teks & 519 & $\begin{array}{c}\text { Deng } \\
\text { an }\end{array}$ & 399 & ini & 412 \\
\hline 8 & teks & 563 & Ini & 502 & $\begin{array}{c}\text { Dala } \\
\text { m }\end{array}$ & 378 & kalian & 402 \\
\hline 9 & pada & 508 & $\begin{array}{c}\text { Untu } \\
\mathrm{k}\end{array}$ & 487 & Ini & 352 & itu & 385 \\
\hline $\begin{array}{l}1 \\
0\end{array}$ & $\begin{array}{c}\text { baha } \\
\text { sa }\end{array}$ & 457 & Atau & 486 & Iklan & 342 & untuk & 341 \\
\hline $\begin{array}{l}1 \\
1 \\
\end{array}$ & Itu & 432 & $\begin{array}{c}\text { Baha } \\
\text { sa }\end{array}$ & 480 & Sebut & 278 & dapat & 317 \\
\hline $\begin{array}{l}1 \\
2 \\
\end{array}$ & $\begin{array}{c}\text { untu } \\
\mathrm{k}\end{array}$ & 429 & Pada & 476 & $\begin{array}{c}\text { Untu } \\
\mathrm{k}\end{array}$ & 266 & dari & 316 \\
\hline $\begin{array}{l}1 \\
3 \\
\end{array}$ & jadi & 418 & $\begin{array}{c}\text { Tida } \\
\mathrm{k}\end{array}$ & 434 & Dari & 232 & tidak & 310 \\
\hline $\begin{array}{l}1 \\
4\end{array}$ & dari & 416 & Baca & 424 & Itu & 227 & pada & 299 \\
\hline $\begin{array}{l}1 \\
5\end{array}$ & atau & 411 & Tulis & 404 & $\begin{array}{c}\text { Perist } \\
\text { iwa }\end{array}$ & 225 & $\begin{array}{c}\text { bahas } \\
\text { a }\end{array}$ & 268 \\
\hline $\begin{array}{l}1 \\
6 \\
\end{array}$ & $\begin{array}{c}\text { kam } \\
\mathrm{u}\end{array}$ & 365 & Dari & 385 & $\begin{array}{c}\text { Bahas } \\
\text { a }\end{array}$ & 217 & atau & 240 \\
\hline $\begin{array}{l}1 \\
7\end{array}$ & $\begin{array}{c}\text { gun } \\
\mathrm{a}\end{array}$ & 364 & $\begin{array}{c}\text { Dap } \\
\text { at }\end{array}$ & 378 & Kata & 205 & $\begin{array}{c}\text { Indon } \\
\text { esia }\end{array}$ & 239 \\
\hline
\end{tabular}

As shown in Table III, from the seventeen major favorite entries, there are two similar entries that occupy the top positions, namely: the (position 1), and (position 2). This is similar to the junior high school books [13]. Only two entries are the vocabulary of the field of science, namely the words "text" and "language" (vocabulary field of Indonesian 
sciences). This favorite entry shows the focus of discussion. This is in accordance with the Indonesian language material held by the Curriculum 2013, which is text based. From other languages, this can be compared to favorite entries in English [12] occupied by "the" (position 1) and then "he" (2nd position).

What is interesting is the use of different greetings. Grade $\mathrm{X}$ uses "you" (singular) greeting, grade XII uses "you" (plural). Basically the two greetings are different because the one for the invidual and the second for the plural. However, both greetings and further refer to different authors.

\section{Learning Scenario}

Based on the results of the analysis conducted, the development of vocabulary in learning Indonesian should use other sources outside the student's book. This is in accordance with the steps in the literacy strategy in learning that the points are invited to read other sources[13]. In the literacy strategy there is also a special point in relation to the development of vocabulary, which is "identifying new vocabulary, keywords, and / or difficult passages" that will be obtained by reading other relevant sources. Using other sources, including other current sources will make the development of vocabularies more massive. Below is a table of learning scenarios with a literacy strategy that identifies life-based learning in its steps.

TABLE IV. VOCABULARY LEARNING SCENARIOS

\begin{tabular}{|c|c|}
\hline $\mathbf{A}$ & A Literacy Strategy in Learning \\
\hline & 1. Before reading \\
\hline & identify the purpose of reading \\
\hline & make predictions \\
\hline & 2. When reading \\
\hline & identify relevant information \\
\hline & $\begin{array}{c}\text { identifying new vocabulary, keywords, and / or difficult text } \\
\text { sections }\end{array}$ \\
\hline & $\begin{array}{l}\text { visualize and / or think aloud (can be assisted by other sources } \\
\text { outside the student's book) }\end{array}$ \\
\hline & $\begin{array}{l}\text { make inference (can be assisted by other sources outside the } \\
\text { student's book) }\end{array}$ \\
\hline & $\begin{array}{l}\text { create questions (can be assisted by other sources outside the } \\
\text { student's book) }\end{array}$ \\
\hline & $\begin{array}{l}\text { making intertextual relation (assisted by other sources outside the } \\
\text { student's book) }\end{array}$ \\
\hline & 3. After reading \\
\hline & create "summary" and evaluation \\
\hline & $\begin{array}{l}\text { changing the modes (assisted by other sources outside the student's } \\
\text { book) }\end{array}$ \\
\hline & $\begin{array}{l}\text { select, combine, and / or produce multimodal text (assisted by } \\
\text { other sources outside the student's book) }\end{array}$ \\
\hline & confirming, revising, or rejecting predictions \\
\hline $\mathbf{B}$ & Use of tools \\
\hline & graphic organizer \\
\hline & check list etc. \\
\hline
\end{tabular}

Based on the table it appears the role of literacy strategy in learning, especially for the development of vocabulary students.

\section{CONCLUSION}

Based on the results of the analysis that has been presented it can be summed up various things as follows: (1) The number of Indonesian entries in the student's book needs to be taken into account in relation to its levelling. The higher the grade should be the more number of entries; (2) Favorite entries are "yang" and "dan". In addition, the favorite field of science (Indonesian) in SMA is "teks" and "bahasa". This is in accordance with the directions of Indonesian language learning in text based on curriculum 2013; (3) Learning scenarios in vocabulary development can be carried out by various means using other sources outside the student's book to further enrich the vocabulary. This is accompanied by a literacy strategy in learning.The results of this study can be used by teachers to further develop the learning to improve students'vocabulary. In the future it is expected that the book levelling in Indonesia will pay attention to the number of entries contained in every series. In addition, research on reading vocabulary and on writing vocabulary from students' writing needs to be always conducted.

\section{REFERENCES}

[1] Depdikbud, Kurikulum Bahasa Indonesia. 1995

[2] Depdiknas, Kurikulum Berbasis Kompetensi. 2000.

[3] Depdiknas, Kurikulum 2013. 2014.

[4] A. Biemiller, "Teaching vocabulary: Early, Direct, Sequential," Am Educ., vol. 25, p. 1, 2001.

[5] Suherli et al, Bahasa Indonesia SMA/MA/SMK Kelas X. Jakarta, 2017.

[6] Suherli et al, Bahasa Indonesia SMA/MA/SMK KELAS XI. Jakarta: Kemdikbud, 2017.

[7] Suherli et al, Bahasa Indonesia SMA/MA/SMK Kelas XII-1. Jakarta: Kemdikbud, 2017.

[8] Suherli et al, Bahasa Indonesia SMA/MA/SMK Kelas XII-2. Jakarta: Kemdikbud, 2017.

[9] K. Laksono, Mintowati, Mukhzamillah, and F. Inayatillah, KosakataBaca dan Kosakata-Tulis Siswa SMP, Surabaya, 2017.

[10] D. Zuchdi, "KB Bahasa Indonesia untuk Sekolah Dasar di Indonesia," Yogyakarta, 1997.

[11] Sarwadi et el, "Penelitian Penguasaan Kosakata Bahasa Indonesia Murid Kelas 6 Sekolah Dasar di Jawa Tengah dan Daerah Istimewa Yogyakarta," 1978.

[12] D. Carrol and Racman, The American Herritage Word Frequency Book”. 1997.

[13] K. Laksono and P. Retnaningdyah, Strategi Literasi dalam Pembelajaran. Jakarta: Dit PSMP, Kemdikbud, 2017. 